\title{
Determinants of Compliance Property Taxpayers: Analysis with Structural Equation Model
}

\author{
Heni Nurani HARTIKAYANTI ${ }^{1 *}$, Ridwan ILYAS ${ }^{2}$, Ifan Wicaksana SIREGAR ${ }^{3}$ \\ 1,2,3 Universitas Jenderal Achmad Yani, Cimahi, Indonesia \\ Email: heni.nurani@lecture.unjani.ac.id¹, ilyas@lecture.unjani.ac.id ${ }^{2}$,ifan.wicaksana.s@lecture.unjani.ac.id ${ }^{3}$ \\ * Corresponding Author
}

\begin{abstract}
Received: 19.08.2021
Accepted: 11.11.2021

Published: 03.12.2021

DOI: $10.47750 / Q A S / 22.185 .11$

\section{Abstract}

This research examines the influence of property tax knowledge, moral obligations, taxpayer awareness, and local government service quality on tax compliance using several statements on a Likert Scale. The accidental sampling method was used to collect data from 499 respondents by distributing and analyzing questionnaires using the structural equation modeling (SEM) with Smart PLS method. The hypothesis test result indicates that moral obligations and property tax knowledge are positively and significantly influenced by tax compliance, meanwhile awareness is negatively affected and local government service quality is positively but insignificantly affected. Furthermore, the moral obligation of taxpayers demonstrates the conditions with the least influence on property taxpayer compliance. Therefore, the government needs to pay adequate attention to the improvement of service quality at the tax office to promote higher outcomes through employee training and socialization.
\end{abstract}

Keywords: property tax knowledge, property taxpayer awareness, moral obligations and local government service quality service, property taxpayer compliance

\section{Introduction}

According to Ali, Fjeldstad and Katera (2017); Ahmad and Brosio (2015), and Mintz and Chen (2011), taxes are a source of funds for economic development in several developed and developing countries. One of the efforts used by countries for independent financial development is by exploring sources of income for the central and regional governments through land and building tax. This is generally used to increase the sources of development funds in the city /state, thereby enhancing economic development (Mintz and Chen, 2011; Shakede and Komolafe, 2017; Kuldeep, 2017). However, in practice, land and building tax are often difficult to successfully implement by the central or local government (Slack and Bird, 2014; Vitor, Osae and Donani, 2015).

Every government makes improvements or reforms in the management of this tax, which has not been fully utilized due to the compliance conditions of taxpayers and poor conditions of the buildings (Ali, Fjeldstad and Katera, 2017; Ahmad and Brosio, 2015;Balogun, 2019; Gangl and Torgler, 2020 and Ciprian, 2015) stated that the revenue from land and building significantly increases a state's economy. However, in most cases, the revenue from taxes and buildings does not meet the expectations, which indicates that the level of taxpayer compliance is not good. Therefore, the government needs to implement various strategies to improve taxpayers' compliance by improving government services (Hermawan, Abigail, Martowidodjo and Tohang, 2020; Guo, Hao and Ren, 2014), calculating tax potential using geographic information system applications, and reforming tax administration (Standiford, Bartolome, Frost and McDougald, 1999; Zoneh, 2021; Javed, Saqib, Razaq and Saeed, 2018).
The low level of property taxpayer compliance in fulfilling their obligations indicates that the behavior of taxpayers is low. According to studies carried out by Nurkhin, Novianty, Muhsin and Sumiadji, 2018; Chucks and Anthony , 2013; Dabor, Kifordu and Abubakar, 2021; Alkhatib, Hamad and Hermas, 2020; Hardika, Wicaksana and Subratha, 2021; Bernard, Memba and Oluoch, 2018; Pratiwi, Maryani, Agustin, Prasetyo and Arnan, 2020, Nguyen, Pham, Le, Truong and Tran, 2020; Setyadi and Sumarsono, 2020; Artawan, Widnyana and Kusuma, 2020 the factors that influence tax compliance are property tax knowledge, moral obligations, awareness of taxpayers, and the quality service of the authorities tax office. This study aims to determine the factors that significantly impact the property taxpayer compliance used as a basis for improving their economic condition.

\section{Literature Review}

\section{Property Tax and Compliance with Land and Building Taxpayers}

In Indonesia, land and building tax is paid by individuals or entities that own, utilize, and control land and buildings. Tax compliance is the behavior of taxpayers in fulfilling their tax obligations by entering and reporting the required information on time, filling out the right amount of tax owed, and ensuring they pay their taxes on time without any audit action due to nonpayment or delay (Wicaksono and Lestari, 2017). Property tax compliance refers to an individual's willingness to pay their tax following the law without the need for tax administrative officers to implement enforcement activities (Saad, 2014). 


\section{GENERAL MANAGEMENT}

\section{Tax Knowledge and Property Tax Compliance}

Property tax knowledge is defined as having a general understanding of the taxation concept applied in Indonesia (Wicaksono and Lestari, 2017). The knowledge of taxation function, tax rules, payment procedures, tax rates, and sanctions are important concepts to be known by every taxpayer (Bernard, Memba and Oluoch, 2018). According to preliminary studies, tax knowledge has a significant positive effect on taxpayer compliance (Nurkhin, Noviantyu, Muhsin, and Sumiadji, 2018; Alkhatib, Hamad and Hermas, 2020; Hardika, Wicaksana and Subratha, 2021; Bernard, Memba and Oluoch, 2018; Chandra Dewi, 2019; Wicaksono and Lestari, 2017; Hantono , 2021). Therefore, the first hypothesis is developed as follow;

$\mathrm{H} 1$ : Tax knowledge has a significant positive effect on taxpayer compliance.

\section{Taxpayer Awareness and Property Tax Compliance}

Awareness is the human element in understanding, responding, and reacting to reality. Awareness of taxpayers means that they know the taxes are a form of community participation in state development, therefore, inability to pay is detrimental to the state (Kami, 2015). Taxpayer awareness in paying taxes on time affects their compliance level and helps the government to understand their attitude, meaning, function, and purpose (Wicaksono and Lestari, 2017). Many people do not know the significant and positive effect of paying tax (Nurkhin, Novianty, Muhsin and Sumiadji, 2018; Pratiwi, Maryani, Agustin, Prasetyo and Arnan, 2020; Setyadi and Sumarsono, 2020; Maghrebi, Ahmad and Palil, 2016; Sania and Yudianto,2018). The second hypothesis is developed as follow;

$\mathrm{H} 2$ : Taxpayer awareness has a significant positive effect on taxpayer compliance

\section{Local Government Quality Service e and Property Taxpayer Compliance}

Quality service is the ability to meet or exceed the expectations of taxpayers. The quality service of the tax office is demonstrated by answering taxpayer complaints, explaining tax rules properly, being reliable in providing information, and having a good understanding of tax rules (Sani and Yudianto, 2018). According to Hadiwijaya and Febrinty (2019), tax authorities are expected to be knowledgeable and experienced in tax policy, administration and law. Subsequently, taxpayers need to be highly motivated as public servants. The service quality of local government staff has a positive effect on the taxpayer's compliance level. Service quality cannot be achieved without process quality (Hermawan, Abigail, Martowidodjo and Tohang, 2020; Artawan, Widnyana and Kusuma, 2020; Sania and Yudianto, 2018; Setiawan, Yuliansyah and Mumpuni, 2020 ; Susuawu, Boateng and amoh, 2020). The third hypothesis is developed as follow;

$\mathrm{H} 3$ : The service quality of local government has a significant positive effect on taxpayer compliance

\section{Moral Obligations and Property Taxpayer Compliance}

Moral obligations are an individual's unique attributes, such as ethics, feelings of guilt, principles of life, and carrying out tax obligations voluntarily and correctly. Purnamasari, and Sudaryo (2018) stated that taxes are actions based on conscience, which also means full actions with freedom in their implementation without any element of coercion. The morality of taxpayers is determined from the feeling that state financing is a shared responsibility, thereby enabling them to pay their taxes voluntarily. The morality of taxpayers greatly affect their compliance (Chucks and Anthony, 2013; Dabor, Kifordu and Abubakar, 2021 Alkhatib, Hamad and Hermas, 2020; Hardika Wicaksana and Subratha, 202; Hantono,2021;Purnamasari and sudaryo, 2018; Marandu, Mbekomize and Ifezue, 2015). The fourth hypothesis is developed as follow;

H4 : The moral obligation of Taxpayer awareness has a significant posit, ive effect on taxpayer compliance

\section{Research Methods}

This research consists of 5 objects, namely taxpayer's tax knowledge, awareness, authority's service quality, morality and individual compliance. The accidental sampling technique was used to collect data from 499 taxpayers registered in Cimahi Tax Office through questionnaires. The data collected were processed to determine its validity and reliability using a $5 \%$ degree of freedom, analyzed using the Structural Equation Modeling with SmartPLS version 2 software, and statistically tested to determine the hypothesis.

\begin{tabular}{|c|c|c|}
\hline No & Analyzed construct & Kode \\
\hline 1 & Tax Knowledge (independent variable) & \\
\hline 1 & I understand what the land and building tax is all about & $\mathrm{P} 1$ \\
\hline 2 & $\begin{array}{l}\text { I understand the rules of the land and building tax in rural and } \\
\text { urban areas }\end{array}$ & P2 \\
\hline 3 & I understand the procedure for paying Land and Building Tax & P3 \\
\hline 4 & $\begin{array}{l}\text { I understand the land and building tax rates set by the local } \\
\text { government }\end{array}$ & $\mathrm{P} 4$ \\
\hline 5 & $\begin{array}{l}\text { I have an adequate understanding of the sanctions associated } \\
\text { with one's inability to pay Land and Building Tax. }\end{array}$ & P5 \\
\hline II & Taxpayer Awareness (independent variable) & \\
\hline 1 & $\begin{array}{l}\text { Tax is a form of community participation in a country's } \\
\text { development }\end{array}$ & K1 \\
\hline 2 & $\begin{array}{l}\text { Delaying the payment of land and building taxes is detrimental to } \\
\text { the state. }\end{array}$ & $\mathrm{K} 2$ \\
\hline 3 & $\begin{array}{l}\text { Land and Building Tax determined by law is also subject to } \\
\text { sanctions }\end{array}$ & K3 \\
\hline
\end{tabular}




\section{GENERAL MANAGEMENT}

\begin{tabular}{|c|c|c|}
\hline 4 & $\begin{array}{l}\text { The collection results of Land and Building Tax are indirectly re- } \\
\text { enjoyed }\end{array}$ & K4 \\
\hline 5 & $\begin{array}{l}\text { Paying land and building taxes on time accelerates the realization } \\
\text { of local government programs. }\end{array}$ & $\mathrm{K} 5$ \\
\hline III & Local Government Service Quality (independent variable) & \\
\hline 1 & $\begin{array}{l}\text { Local government staff provides clear socialization of Land and } \\
\text { Building taxes. }\end{array}$ & $\mathrm{K} 11$ \\
\hline 2 & $\begin{array}{l}\text { Local government staff serve and answer every complaint } \\
\text { adequately }\end{array}$ & $\mathrm{K} 12$ \\
\hline 3 & $\begin{array}{l}\text { The local government staff properly explains the regulations on } \\
\text { land and building taxes. }\end{array}$ & $\mathrm{K} 13$ \\
\hline 4 & $\begin{array}{l}\text { Local government staff is relied on in providing information on land } \\
\text { and building taxes. }\end{array}$ & K14 \\
\hline 5 & $\begin{array}{l}\text { Local government staff understands the rules of Land and Building } \\
\text { Tax in accordance with applicable regulations. }\end{array}$ & $\mathrm{K} 15$ \\
\hline IV & Moral Obligations (independent variable) & \\
\hline 1 & The responsibility for state financing is shared & M1 \\
\hline 2 & $\begin{array}{l}\text { A feeling of anxiety arises whenever I don't pay the Land and } \\
\text { Building Tax }\end{array}$ & M2 \\
\hline 3 & $\begin{array}{l}\text { There is a feeling of guilt assuming I fail to pay my land and } \\
\text { Building tax on time. }\end{array}$ & M3 \\
\hline 4 & I fulfill my Land and Building Tax obligations voluntarily & M4 \\
\hline 5 & $\begin{array}{l}\text { I feel that paying Land and Building Tax is an obligation I must } \\
\text { perform to contribute to the state. }\end{array}$ & M5 \\
\hline V & Taxpayer Compliance (dependent variable) & \\
\hline 1 & I will always pay my Land and Building Tax obligations & Kp1 \\
\hline 2 & I am aware of the need to pay Land and Building Tax & $\mathrm{Kp} 2$ \\
\hline 3 & Land and building tax payment is my responsibility & Kp3 \\
\hline 4 & I am willing to pay Land and Building Tax & Kp4 \\
\hline 5 & I pay Land and Building Tax without delay & Kp5 \\
\hline
\end{tabular}

Table 1: Research Variables

\section{Result And Discussion}

\section{Descriptive Statistics}

Descriptive statistics on the exogenous variable of Taxpayer Moral Obligations and the influencing indicators are used to obtain information capable of preventing respondents from being non-compliant with taxes. Furthermore, it is used to obtain negative information that influences Taxpayer Awareness and the inability of the local government to provide adequate service quality. Descriptive Statistics on the exogenous variable of Tax Knowledge and the influencing indicators are used to obtain information that functions adequately according to taxation rules for lands and buildings. These statistics on the endogenous variable of Taxpayer Compliance and the influencing indicators are used to obtain information that none of the respondents agree that a taxpayer must have an NPWP for identification.

\section{Hypothesis Testing}

\section{Outer Model Test (Indicator Test)}

The measurement results of the model are declared valid, assuming they have a loading factor above 0.5 for the intended construct. The SmartPLS output for the loading factor is shown in Table 2

\begin{tabular}{|l|l|l|l|l|l|l|l|}
\hline No & Analyzed construct & Kode & $\begin{array}{l}\text { Loading } \\
\text { Factor }\end{array}$ & AVE & CR & CA & CM \\
\cline { 1 - 2 } & Tax Knowledge & & 0.7413 & 0.9347 & 0.9128 & 0.7413 \\
\hline 1 & $\begin{array}{l}\text { I have adequate knowledge of the } \\
\text { land and building tax }\end{array}$ & P1 & 0.8755 & & & & \\
\hline 2 & $\begin{array}{l}\text { I understand the rules of the land } \\
\text { and building tax in rural and urban } \\
\text { areas }\end{array}$ & P2 & 0.8627 & & & & \\
\hline 3 & $\begin{array}{l}\text { I understand the procedure for } \\
\text { paying Land and Building Tax }\end{array}$ & P3 & 0.8915 & & & & \\
\hline 4 & $\begin{array}{l}\text { I understand the land and building } \\
\text { tax rates set by the local government }\end{array}$ & P4 & 0.8509 & & & & \\
\hline
\end{tabular}




\section{GENERAL MANAGEMENT}

\begin{tabular}{|c|c|c|c|c|c|c|c|}
\hline 5 & $\begin{array}{l}\text { I understand the sanctions } \\
\text { associated with one's inability to pay } \\
\text { Land and Building Tax. }\end{array}$ & P5 & 0.8227 & & & & \\
\hline II & Taxpayer Awareness & & & 0.7745 & 0.9449 & 0.9276 & 0.7745 \\
\hline 1 & 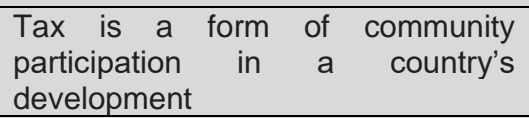 & K1 & 0.9075 & & & & \\
\hline 2 & $\begin{array}{l}\text { Delaying the payment of land and } \\
\text { building taxes is detrimental to the } \\
\text { state. }\end{array}$ & K2 & 0.8983 & & & & \\
\hline 3 & $\begin{array}{l}\text { Land and Building Tax is determined } \\
\text { by the law and can be subject to } \\
\text { sanctions }\end{array}$ & K3 & 0.8717 & & & & \\
\hline 4 & $\begin{array}{l}\text { The collection results of Land and } \\
\text { Building Tax are indirectly enjoyed }\end{array}$ & K4 & 0.8692 & & & & \\
\hline 5 & $\begin{array}{l}\text { Paying land and building taxes on } \\
\text { time accelerates the realization of } \\
\text { local government programs. }\end{array}$ & K5 & 0.8524 & & & & \\
\hline III & $\begin{array}{lll}\text { Local } & \text { Government } & \text { Service } \\
\text { Quality } & & \\
\end{array}$ & & & 0.7210 & 0.9278 & 0.9038 & 0.7210 \\
\hline 1 & $\begin{array}{l}\text { Local government staff provides } \\
\text { clear socialization of Land and } \\
\text { Building taxes. }\end{array}$ & K11 & 0.8245 & & & & \\
\hline 2 & $\begin{array}{l}\text { Local government staff serve and } \\
\text { answer every complaint properly }\end{array}$ & K12 & 0.9048 & & & & \\
\hline 3 & $\begin{array}{l}\text { The local government staff the } \\
\text { regulations on land and building } \\
\text { taxes properly. }\end{array}$ & K13 & 0.8943 & & & & \\
\hline 4 & $\begin{array}{l}\text { Local government staff are relied } \\
\text { upon in providing information on land } \\
\text { and building taxes. }\end{array}$ & K14 & 0.8782 & & & & \\
\hline 5 & $\begin{array}{l}\text { Local government staff adequately } \\
\text { understand the rules of Land and } \\
\text { Building Tax in accordance with } \\
\text { applicable regulations. }\end{array}$ & K15 & 0.7317 & & & & \\
\hline IV & Moral Obligations & & & 0.6894 & 0.9169 & 0.8855 & 0.6894 \\
\hline 1 & $\begin{array}{l}\text { The responsibility for state financing } \\
\text { is a shared }\end{array}$ & M1 & 0.7129 & & & & \\
\hline 2 & $\begin{array}{l}\text { There is a feeling of anxiety that } \\
\text { arises when one fails to pay Land } \\
\text { and Building Tax. }\end{array}$ & M2 & 0.8592 & & & & \\
\hline 3 & $\begin{array}{l}\text { There is a feeling of guilt whenever I } \\
\text { fail to pay the Land and Building tax } \\
\text { on time. }\end{array}$ & M3 & 0.8643 & & & & \\
\hline 4 & $\begin{array}{l}\text { I fulfill my Land and Building Tax } \\
\text { obligations voluntarily }\end{array}$ & M4 & 0.8780 & & & & \\
\hline 5 & $\begin{array}{l}\text { I feel that paying Land and Building } \\
\text { Tax is an obligation to contribute to } \\
\text { the state. }\end{array}$ & M5 & 0.8260 & & & & \\
\hline $\mathbf{V}$ & Taxpayer Compliance & & & 0.7861 & 0.9433 & 0.9317 & 0.7861 \\
\hline 1 & $\begin{array}{l}\text { I will always pay my Land and } \\
\text { Building Tax obligations }\end{array}$ & Kp1 & 0.8958 & & & & \\
\hline 2 & $\begin{array}{l}\text { I know I have to pay Land and } \\
\text { Building Tax }\end{array}$ & Kp2 & 0.9113 & & & & \\
\hline 3 & $\begin{array}{l}\text { Land and building tax payment is my } \\
\text { responsibility }\end{array}$ & Kp3 & 0.9099 & & & & \\
\hline 4 & $\begin{array}{l}\text { I am willing to pay Land and Building } \\
\text { Tax }\end{array}$ & Kp4 & 0.8455 & & & & \\
\hline 5 & I pay Land and Building Tax on time & Kp5 & 0.868791 & & & & \\
\hline
\end{tabular}

Table 2: Construct Measurement Model

The validity of a reflective indicator is tested to determine the correlation between the scores of items and constructs.
Measurements using a reflective indicator indicate a change in construct, assuming others are removed from the model. 


\section{GENERAL MANAGEMENT}

Reflective indicators are suitable for measuring the perception used by this study which has a loading factor value above 0.5 . The smallest is 0.7129 for the M1 indicator (Moral obligations), hence the indicators used in this study are valid.

Furthermore, reflective indicators also need to be tested for discriminant validity by looking at the value of the square root of average variance extracted (AVE). Table 2 shows AVE values above 0.5 for all constructs contained in the research model, with the lowest at 0.6894 in the moral obligation construct.

Reliability testing is carried out by analyzing the value of the block of composite reliability indicator is satisfactory above 0.7 . This indicates that all constructs in the model were estimated and met the criteria of discriminant validity. The reliability of a composite value below 0.9169 indicates moral obligation.

Cronbach's Alpha can also strengthen the reliability test with the recommended value above 0.6 , as shown in Table 2 . The lowest value is 0.8855 in the moral obligation construct. Furthermore, the measurement of Communality with the Smart PLS Version 2 program gives communality values in all constructs above 0.5, which strengthens the test results with Composite Reliability and Cronbach's Alpha. The lowest value is 0.6894 in the moral obligation construct. The following is a diagram of the loading factor of each indicator in the research model:

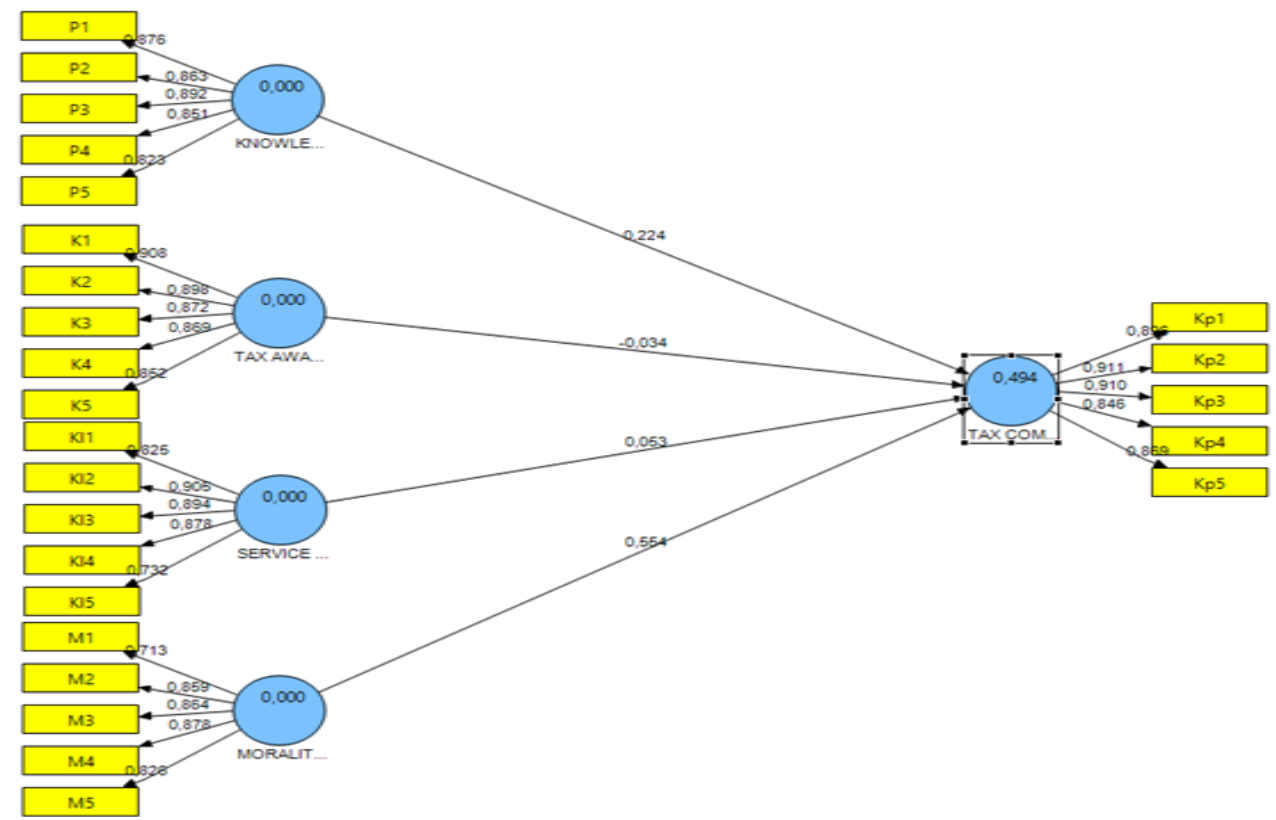

Figure 1: Diagram of Loading Factors

\section{Inner Model Test (Test Effect/Test Hypothesis)}

Inner model testing is carried out by analyzing the value of the coefficient of determination R-square (R2), t-test, and the parameter coefficient Stone-Geisser Q-square (Q2) test. Based on Figure 1, the R-Square value in the construct is 0.494144 , which means that tax knowledge, moral obligations, taxpayer awareness, and service quality have the ability to explain the compliance variance of $49.414 \%$. Meanwhile, the remaining effect of 0.505856 or $50.58 \%$ ( $1-0.494144)$ is caused by other variables outside this study.

An R-square dependent latent variable has the same interpretation as regression, while Q-Square predictive relevance for structural models is used to determine the observed values generated by the model of the estimated parameters. Q-Square calculation is carried out using the formula: Q2 = $1-(1-1-0.494144)$ where Q2 equals 0.494144 . The magnitude of $\mathrm{Q} 2$ has a value with a range of $0<\mathrm{Q} 2<1$, where the closer to 1 , the better the model. Another objective of SEM testing is to estimate the effect of each parameter among the existing variables to test the established hypothesis. The following are the results of the tests that were performed.

\begin{tabular}{|l|l|l|l|l|l|}
\hline & $\begin{array}{l}\text { Original } \\
\text { Sample (O) }\end{array}$ & $\begin{array}{l}\text { Sample Mean } \\
\text { (M) }\end{array}$ & $\begin{array}{l}\text { Standard } \\
\text { Deviation } \\
\text { (STDEV) }\end{array}$ & $\begin{array}{l}\text { Standard Error } \\
\text { (STERR) }\end{array}$ & $\begin{array}{l}\text { T Statistics } \\
\text { (|O/STERR|) }\end{array}$ \\
\hline $\begin{array}{l}\text { Tax Knowledge -> Tax } \\
\text { Compliance }\end{array}$ & 0,224404 & 0,225075 & 0,108184 & 0,108184 & 2,074280 \\
\hline $\begin{array}{l}\text { Moral Obligations > Tax } \\
\text { Compliance }\end{array}$ & 0,553758 & 0,550737 & 0,103926 & 0,103926 & 5,328396 \\
\hline $\begin{array}{l}\text { Service Quality -> Tax } \\
\text { Compliance }\end{array}$ & 0,052547 & 0,059182 & 0,093281 & 0,093281 & 0,563321 \\
\hline $\begin{array}{l}\text { Tax Awareness -> Tax } \\
\text { Compliance }\end{array}$ & $-0,034185$ & $-0,034710$ & 0,108496 & 0,108496 & 0,315084 \\
\hline
\end{tabular}

Table 3: Path Coefficients (Mean, STDEV, T-Values) 


\section{GENERAL MANAGEMENT}

The table above shows a significant relationship between tax knowledge and compliance, with a T-statistic value of 2.022155 (> 1.96). The original estimate value of 0.224404 indicates that the direction of the relationship between knowledge and compliance is positive. The relationship between awareness and compliance is insignificant with a T-statistic of 0.326478 (< 1.96) because the original sample estimate is negative, hence the direction of the relationship between awareness and compliance is negative. Meanwhile, the relationship between service quality and compliance is insignificant, with a T-statistic of $0.566843(<1.96)$. The original sample estimate value is 0.052547 , which indicates that the direction of the relationship between service quality and compliance is positive. The correlation between moral obligation and compliance is significant with a T-statistic of 5.053573 (> 1.96). The original sample estimate value is 0.553758 , which indicates that the direction of the relationship between moral obligation and compliance is positive.

Based on the original sample, the highest value that affects compliance is the moral obligation of 0.553758 , which has a higher moral obligation in compliance with the influence of tax knowledge. Therefore, moral obligation is the most dominant variable in influencing compliance. The following is a diagram of the statistical $T$ value based on the output with SmartPLS Version 2 .

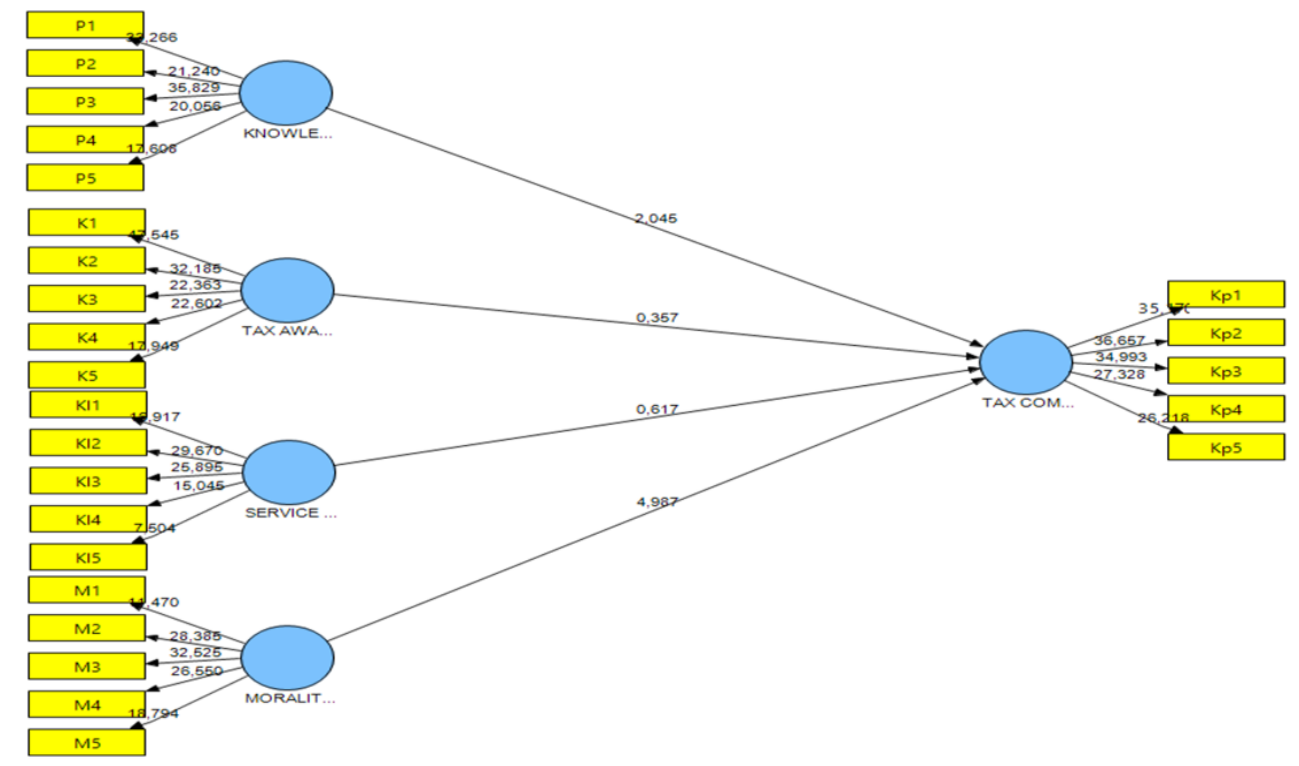

Figure 2: Diagram of the statistical T

This study is useful for local governments that are directly related to the management of land and building taxes to meet the costs of city development. Hypothesis testing shows that the knowledge of taxpayers' has a positive and significant effect on the compliance of land and building taxpayers. In this case, the Cimahi City Government needs to pay special attention to maintaining taxpayers' knowledge of tax rules. The empirical data obtained support the proposed hypothesis and are in line with preliminary studies, which stated that knowledge of taxpayers has a positive effect on their compliance (Nurkhin,Novianty, Muhsin and Sumiadji,2018; Alkhatib, Hamad and Hermas,2020; Hardika,Wicaksana and Subratha, 2021; Bernard, Memba and Oluoch,2018; Wicaksono and Lestari,2017; Saad, 2014;Chandra Dewi, 2019; Kamil, 2015).

Furthermore, this study also explained the awareness of taxpayers to comply with tax obligations without a significant negative effect on tax compliance. Awareness basically arises due to taxpayers' need to get something for the government or associated community. These results are not in accordance with preliminary studies.

Empirical data show that the service quality of tax officers has a positive and insignificant effect on taxpayers. These result are not in line with preliminary studies. Therefore, it is imperative to improve the service quality of office staff and understand tax rules for the staff services to be more reliable and increase taxpayer satisfaction. This also tends to increase their awareness and compliance with tax obligations. However, these results are not in line with previous studies that stated that the quality of employee services positively affects increasing taxpayer compliance. Consequently, adequate attention is needed from the tax office in terms of improving staff capability to rules.

The test results also showed that the moral obligation of taxpayers has a positive and significant effect on their compliance. Those with moral responsibility tend to obey in carrying out their tax obligations. These results correspond with preliminary studies, which stated that the moral obligation of taxpayers has a positive and significant effect on their compliance (Chucks and Anthony, 2013; Dabor, Kifordu and Abubakar, 2021; Alkhatib, Hamad and Hermas, 2020, Sania and Yudianto, 2018). This is also in line with the results of research in several countries in Europe, Asia and America, that high tax morale will have a strong effect on tax compliance (Kemme, Parikh and Steigner, 2020, Torgler, Schaffner and Macintyre, 2021). Several factors that influence tax morale include institutional quality, politics, tax regulation reform, education level, economic progress, legal system ( Yücedoğru and Hasseldine, 2021; Williams and Krasniqi, 2017; Sá, Martins and Gomes,2021, Alm and Torgler, 2006; Luttmer and Singhal, 2014; Frey and torgler, 2007, Ahmad, Ezhawati, Latif, Zainuddin and Yatim, 2019; Kiow, Claudia, Kassim and Salleh,). 2021

\section{Conclusion}

This study shows that tax knowledge and moral obligations positively and significantly affect taxpayer compliance in paying 
land and building tax obligations. Furthermore, taxpayer awareness has a negative and significant effect on compliance, with a positive and insignificant effect on tax office staff. This suggests the government should focus on service quality to increase awareness and tax compliance. Therefore, further research needs to be conducted using several other factors and additional respondents.

\section{References}

[1] Alkhatib, A. A., Hamad, M. Z., \& Hermas, M. D. (2020). The Impact of Tax Ethics and Knowledge on Tax Compliance among Palestinian Taxpayers. International Journal of Academic Research in Business and Social Sciences, 10(6). doi:10.6007/ijarbss/v10-i6/7305

[2] Chucks, A. D. (2013). Tax Morale and Its Effect on Taxpayers' Compliance to Tax Policies of the Nigerian Government. IOSR Journal of Business and Management, 12(6), 35-55. doi:10.9790/487x-1263555

[3] Sania, A. F., \& Yudianto, I. (2018). Analysis of Factors that Influence Taxpayers Compliance in Fulfilling their Taxation Obligations: Study of Small Medium Entrepreneur (SMEs) Taxpayers Based on eCommerce in the Bandung Area. Journal of Accounting Auditing and Business, 1(2), 17. doi:10.24198/jaab.v1i2.18270

[4] Nurkhin, A., Novanty, I., Muhsin, M., \& Sumiadji, S. (2018). The Influence of Tax Understanding, Tax Awareness and Tax Amnesty toward Taxpayer Compliance. Jurnal Keuangan Dan Perbankan, 22(2). doi:10.26905/jkdp.v22i2.1678

[5] O. Dabor, A. A. Kifordu, and J. A. Abubakar, "Tax Compliance Behavior and Religiosity: The role of Morality," Palarch's Journal of Archaeology of Egypt/Egyptology 18 (1), pp. 3911-3935, 2021.

[6] Frey, B. S., \& Torgler, B. (2007). Tax morale and conditional cooperation. Journal of Comparative Economics, 35(1), 136-159. doi:10.1016/j.jce.2006.10.006

[7] Torgler, M. Schaffner, and A. Macintyre, "Tax Compliance, Tax Compliance, Tax Morale, and Governance Quality," 2007, Accessed: Oct. 15, 2021. [Online]. Available: http://ispaysps.gsu.edu

[8] Williams, C. C., \& Krasniqi, B. (2017). Evaluating the individualand country-level variations in tax morale. Journal of Economic Studies, 44(5), 816-832. doi:10.1108/jes-09-2016-0182

[9] Sá, A. Martins, and C. Gomes, "Tax Morale Determinants In Portugal," European Scientific Journal, ESJ, Sep. 2015, Accessed: Oct. 15, 2021. [Online]. Available: https://eujournal.org/index.php/esj/article/view/6152

[10] Setiawan, D. A., Yuliansyah, R., \& Mumpuni, S. R. (2020). The Influence of Understanding, Taxation Sanction, and Level of Trust in Government for Taxpayer Compliance for Pay Property Tax (Empirical Study of PBB-P2 Taxpayers Registered in Jatinegara Sub-District). Proceedings of the Annual International Conference on Accounting Research (AICAR 2019). doi:10.2991/aebmr.k.200309.039

[11] Awunyo-Vitor, D., Osae, E. O., \& Donani, S. (2015). Determinants of property rate default: evidence from the Ashanti Region, Ghana. Commonwealth Journal of Local Governance, 190-203. doi:10.5130/cjlg.v0i0.4494

[12] Kemme, D. M., Parikh, B., \& Steigner, T. (2020). Tax Morale and International Tax Evasion. Journal of World Business, 55(3), 101052. doi:10.1016/j.jwb.2019.101052

[13] Purnamasari, D., \& Sudaryo, Y. (2018). The Effect of Knowledge Taxpayer, Moral Taypayer and Tax Sanctions on Taxpayers Compulsory. International Journal of Trade, Economics and Finance, 9(5), 214-219. doi:10.18178/ijtef.2018.9.5.618

[14] Susuawu, D., Ofori-Boateng, K., \& Amoh, J. K. (2020). DOES SERVICE QUALITY INFLUENCE TAX COMPLIANCE BEHAVIOUR OF SMES? A NEW PERSPECTIVE FROM GHANA. International Journal of Economics and Financial Issues, 10, 50-56. doi:10.32479/ijefi.10554

\section{Acknowledgments}

The authors are grateful to the Ministry of Education and Culture, Research and Technology and Higher Education for funding this PTUPT Program research, which is beneficial for developing science and practice regarding tax management.

[15] Ahmad and G. Brosio, Handbook of Multilevel Finance. Edward Elgar Publishing, 2015. [Online]. Available: http://www.elgaronline.com/view/9780857932280.xml

[16] Marandu, E. E., Mbekomize, C. J., \& Ifezue, A. N. (2015). Determinants of Tax Compliance: A Review of Factors and Conceptualizations. International Journal of Economics and Finance, 7(9). doi:10.5539/ijef.v7n9p207

[17] Luttmer, E. F. P., \& Singhal, M. (2014). Tax Morale. Journal of Economic Perspectives, 28(4), 149-168. doi:10.1257/jep.28.4.149

[18] E. Slack and R. Bird, "The Political Economy of Property Tax Reform," OECD Publishing, 2014. [Online]. Available: https://econpapers.repec.org/paper/oecctpaab/18-en.htm

[19] Hadiwijaya, H., \& Febrianty, F. (2019). The Effect of Service Quality and Tax Sanctions on Service Satisfaction. ETIKONOMI, 18(2), 197-208. doi:10.15408/etk.v18i2.7428

[20] Hantono. (2021). THE IMPACT TAX KNOWLEDGE, TAX AWARENESS, TAX MORALE TOWARD TAX COMPLIANCE BOARDING HOUSE TAX. International Journal of Research GRANTHAALAYAH, 9(1), doi:10.29121/granthaalayah.v9.i1.2021.2966

[21] G. P. Artawan, I. W. Widnyana, and I. G. A. T. Kusuma, "The Effect of Service Quality to Build Taxpayer Trust and Satisfaction on Increasing Taxpayer Compliance in Gianyar Regency," International Journal of Contemporary Research and Review, vol. 11 , no. 09 , pp. 21868-21883, 2020, doi: 10.15520/ijcrr.v11i09.842.

[22] Alm, J., \& Torgler, B. (2006). Culture differences and tax morale in the United States and in Europe. Journal of Economic Psychology, 27(2), 224-246. doi:10.1016/j.joep.2005.09.002

[23] Guo, J., Hao, A., \& Ren, Y. (2014). Design optimization of real estate tax and effect analysis in China. Journal of Industrial Engineering and Management, 7(2). doi:10.3926/jiem.1015

[24] Mintz, J., \& Chen, D. (2011). Small Business Taxation: Revamping Incentives to Encourage Growth. SSRN Electronic Journal. doi:10.2139/ssrn.1920866

[25] Gangl, K., \& Torgler, B. (2019). How to Achieve Tax Compliance by the Wealthy: A Review of the Literature and Agenda for Policy. Social Issues and Policy Review, 14(1), 108-151. doi:10.1111/sipr.12065

[26] Ahmad, N. Ezhawati, A. Latif, Z. N. Zainuddin, and N. Yatim, "The determinants of tax morale: Survey evidence from undergraduate students," The 3rd International Conference on Accounting Research and Education (iCARE2019)2019. [Online]. Available: https://www.researchgate.net/publication/344299579

[27] Ali, O.-H. Fjeldstad, and L. Katera, "Property Taxation in Developing Countries," CMI Brief, vol. 1, 2017, Accessed: Oct. 15, 2021. [Online]. Available: https://www.cmi.no/publications/6167-property-taxation-indeveloping countries

[28] M. G. Setyadi and N. D. Sumarsono, "Analysis Of Anthesedent And Taxpayer Awareness Consequents Of Compliance Levels In Fulfill Its Taxation Obligationa," International Journal of Economics, Business and Accounting Research (IJEBAR), vol. 4, no. 4, 2020, doi: 10.29040/ijebar.v4i4.1563.

[29] M. S. Al-Maghrebi, R. Ahmad, and M. R. Palil, "Budget Transparency And Tax Awareness Towards Tax Compliance: A Comceptual Approach," South East Asia Journal of Contemporary Business, Economics and Law, 2016, vol. 10, no. 1.

[30] Hermawan, M. S., Abigail, P., Martowidodjo, Y. H., \& Tohang, V. (2020). Understanding tax amnesty and tax compliance in indonesia: an institutional approach. Journal of Economics, 


\section{GENERAL MANAGEMENT}

Business, \& Accountancy Ventura, 22(3). doi:10.14414/jebav.v22i3.1810

[31] Wicaksono, M., \& Lestari, T. (2017). EFFECT OF AWARENESS, KNOWLEDGE AND ATTITUDE OF TAXPAYERS TAX COMPLIANCE FOR TAXPAYERS IN TAX SERVICE OFFICE BOYOLALI. International Journal of Economics, Business and Accounting Research (IJEBAR), 1(01). doi:10.29040/ijebar.v1i01.236

[32] Kamil, "The Effect of Taxpayer Awareness, Knowledge, Tax Penalties and Tax Authorities Services on the Tax Complience: (Survey on the Individual Taxpayer at Jabodetabek \& Bandung)," Research Journal of Finance and Accounting www.iiste.org ISSN, vol. 6, no. 2, 2015, Accessed: Oct. 15, 2021. [Online]. Available: www.iiste.org

[33] Javed, N., Saqib, E., Razaq, A., \& Saeed, U. (2018). Revamping Urban Immovable Property Tax System by Using GIS and MIS: A Case Study of Reforming Urban Taxation Systems Using Spatial Tools and Technology. Comprehensive Geographic Information Systems, 272-296. doi:10.1016/b978-0-12-409548-9.09691-3

[34] Hardika, N. S., Wicaksana, K. A. B., \& Subratha, I. N. (2021). The Impact of Tax Knowledge, Tax Morale, Tax Volunteer on Tax Compliance. Proceedings of the International Conference on Applied Science and Technology on Social Science (ICAST-SS 2020). doi:10.2991/assehr.k.210424.020

[35] Saad, N. (2014). Tax Knowledge, Tax Complexity and Tax Compliance: Taxpayers' View. Procedia - Social and Behavioral Sciences, 109, 1069-1075. doi:10.1016/j.sbspro.2013.12.590

[36] Bernard, O. M., S. Memba, D. F., \& Oluoch, D. O. (2018). Influence of Tax Knowledge and Awareness on Tax Compliance Among Investors in the Export Processing Zones in Kenya. International Journal of Scientific Research and Management, 6(10). doi:10.18535/ijsrm/v6i10.em01

[37] Kuldeep, "Applications of GIS: Property Tax Mapping and Management System," 17th Esri India User Conference 2017, pp. 1-9, 2017, [Online]. Available: https://www.esri.in/ /media/esriindia/files/pdfs/events/2017/UC/proceedings/URBANINFRASTRUCTURE/UCP17007-Property-Tax-Mapping-andManagement-System

[38] P. Shakede and M. O. Komolafe, "Unfolding the Potentials of Geographic Information System on Property Taxation in Lagos State," Covenant Journal of Research in the Built Environment, vol. 5, no. 2, 2017, [Online]. Available: https://journals.covenantuniversity.edu.ng/index.php/cjrbe/article

\section{/view/721}

[39] Standiford, R. B., Bartolome, J. W., Frost, W., \& McDougald, N. (1999). Using GIS in Agricultural Land Assessment for Property Taxes. Annals of GIS, 5(1), 47-51. doi:10.1080/10824009909480513

[40] Chandra Dewi, R. (2019). The Influence of Taxation Knowledge, Awareness of Tax Payers, And the Effectiveness of the Tax System against Taxpayer Compliance (Study on the Tax Payers of Private Entrepreneurs in the Cikarang Region). Saudi Journal of Economics and Finance, 03(10), 427-434 doi:10.36348/sjef.2019.v03i09.008

[41] R. Yücedoğru and J. Hasseldine, "Understanding tax morale of SMEs: A qualitative study," eJournal of Tax Research , vol. 14 no. 3, pp. 531-566, 2016, Accessed: Oct. 15, 2021. [Online]. Available: http://acikarsiv.beun.edu.tr/xmlui/handle/20.500.12628/8427

[42] Ciprian, S. (2015). A Comparative Analysis Of Property Taxation Within European Union. International Journal Vallis Aurea, 1(1), 65-73. doi:10.2507/ijva.1.1.6.6

[43] Balogun, T. F. (2019). An Assessment of Property Tax Administration in Edo State, Nigeria. Indonesian Journal of Geography, 51(1), 69. doi:10.22146/ijg.18843

[44] T. S. Zoneh, "A GIS-Based Real Estate Tax Information System The Case Study of Sinkor District, Monrovia - Liberia," 2013. Accessed: Sep. 24, 2021. [Online]. Available: http://ir.knust.edu.gh/bitstream/123456789/5510/1/Final\%20The sis.pdf

[45] Swee Kiow, T., Claudia, L., Md Kassim, A. A., \& Mohd Salleh, M. F. (2021). The Moderating Effect of Individual Taxpayers Education Level on Ethical Perception and Tax Compliance Behaviour in Peninsular Malaysia. International Journal of Academic Research in Accounting, Finance and Management Sciences, 11(1). doi:10.6007/ijarafms/v11-i1/8857

[46] NGUYEN, T. T. D., PHAM, T. M. L., LE, T. T., TRUONG, T. H. L., \& TRAN, M. D. (2020). Determinants Influencing Tax Compliance: The Case of Vietnam. The Journal of Asian Finance, Economics and Business, 7(2), 65-73. doi:10.13106/jafeb.2020.vol7.no2.65

[47] P. Pratiwi, M. Maryani, R. D. Agustin, B. Prasetyo, and S. Arnan, "The Effect Of Taxpayer Awareness And Modernization Of Tax Administration System On Personal Taxpayer Compliance," PalArch's Journal of Archaeology of Egypt vol 17 no 4, pp. 2741 $-2748,2020$ 